REMLATE DE MUALIES

Campinas-SP, v.39, n.1, pp. 246-264, jan./jun. 2019

\title{
MÁrio de ANDRAde E O APOCALIPSE \\ DAS IMAGENS
}

\section{Mário de Andrade ANd THe Apocalypse OF IMAGES}

\author{
Eduardo Sterzi ${ }^{1}$
}

Resumo: Mário de Andrade foi um colecionador de imagens, tanto suas - os desenhos e fotos que produziu ao longo da vida -, quanto alheias - obras brasileiras e estrangeiras, dos mais variados gêneros, formatos e técnicas, que foi adquirindo ou ganhando de presente. Por outro lado, sua obra literária tem sido recriada imageticamente com notável frequência, seja em capas ou ilustrações dos livros, seja em telas e outros suportes pictóricos, seja em filmes, peças de teatro ou mesmo desfiles de carnaval. A partir dessas duas coleções sobrepostas, buscaremos pensar sobre os lugares ocupados pelas imagens no cruzamento de pesquisa histórica e antropológica, reflexão crítica e criação literária que singularizam esse autor: podemos depreender daí alguma teoria da imagem? Essa teoria da imagem, se existir, guiou a concepção e realização dos seus livros?

Palavras-chave: Mário de Andrade; Macunaíma; imagens.

\begin{abstract}
Mário de Andrade was a collector of images: his drawings and the photos that he has produced throughout his life, but also Brazilian and foreign works of the most varied genres, formats and techniques, which he acquired or won as a gift. On the other hand, his literary work has been recreated with remarkable frequency, whether in covers or illustrations of books, in canvases and other pictorial supports, or in films, plays or even carnival parades. From these two overlapping collections, we will try to think about the places occupied by the images at the intersection of historical and anthropological research, critical reflection and literary creation that singles out this author: can we deduce from this some image theory? Does this image theory, if it exists, have guided the conception and achievement of his books?
\end{abstract}

Keywords: Mário de Andrade; Macunaíma; Images.

1 Professor do Departamento de Teoria Literária da Universidade Estadual de Campinas (Unicamp): <eduardosterzi@gmail.com>. 
Mário de Andrade foi um colecionador de imagens, tanto suas os desenhos e fotos que produziu ao longo da vida -, quanto alheias obras brasileiras e estrangeiras, dos mais variados gêneros, formatos e técnicas, que foi adquirindo ou ganhando de presente. Essa coleção ${ }^{2}$ encontra-se atualmente sob a responsabilidade do Instituto de Estudos Brasileiros da Universidade de São Paulo (USP), e a própria casa em que Mário viveu por muitos anos foi transformada em museu, reunindo, entre objetos pertencentes ao escritor, réplicas de algumas daquelas imagens. Vale lembrar que também a obra literária de Mário tem sido recriada imageticamente com notável frequência, seja em capas ou ilustrações dos livros, seja em telas e outros suportes pictóricos, seja em filmes, peças de teatro ou mesmo desfiles de carnaval (não esqueçamos que a dimensão performática é também uma dimensão da imagem), ou ainda em quadrinhos, instalações, vídeos etc. Podemos ver, nesse conjunto de recriações ou variações que são, antes de tudo, explorações das potencialidades da obra de Mário de Andrade, uma segunda coleção de imagens que, somada àquela outra, a dos papéis e telas efetivamente reunidos pelo escritor, nos conduz a uma série de indagações sobre os lugares ocupados pelas imagens no cruzamento de pesquisa histórica e antropológica, reflexão crítica e criação literária que singulariza esse autor: podemos depreender daí alguma teoria da imagem? Essa teoria da imagem, se existir, guiou a concepção e realização dos seus livros? Um livro como Macunaíma pode ser lido como um museu imaginário ou, segundo outro paradigma, como um atlas de imagens?3 Podemos extrair daí algum modelo para a renovação do modo como compreendemos as imagens? O corpo selvagem, que Macunaíma busca apreender sem domesticar de todo, ${ }^{4}$ cabe nos espaços (físicos e imaginários) reservados convencionalmente às imagens ou nos obriga a alargar, extrapolar ou mesmo explodir tais espaços? Não espero, aqui, oferecer respostas a essas perguntas - mas, pelo contrário, gostaria de alongá-las, gostaria de fazer com que se desdobrem em outras tantas questões.

2 Cf. Rossetti Batista e Soares de Lima (1998).

3 A oposição dos dois paradigmas é central em Didi-Huberman (2013), especialmente no capítulo "Le trésor des chefs-d'œuvre et la clôture du champ esthétique" (pp. 85-123).

4 Cf. Sterzi (2017, pp. 219-222) e Sterzi e Stigger (2017).

Remate de Males, Campinas-SP, v.39, n.1, pp. 246-264, jan./jun. 2019 - 247 
Numa carta datada de 29 de outubro de 1929, Carlos Drummond de Andrade informa a Mário de Andrade que Pedro Nava ilustrara um exemplar de Macunaíma para depois enviá-lo ao autor (SANTIAGO, 2002, p. 359). Na sua resposta, de 19 de novembro, Mário diz: "Fiquei desesperado pra ver o Macunaíma ilustrado pelo Nava. Sempre secretamente desejei ver interpretações alheias dum livro que tem um lado objetivo tão fortemente visível como Macunaíma" (SANTIAGO, 2002, p. 363). O exemplar só seria enviado por Nava a Mário alguns anos depois. Traz oito ilustrações a guache, que ocupam as páginas deixadas em branco na edição.

Os termos da carta de Mário a Drummond, no tocante às ilustrações, pedem atenção. O desejo de "ver interpretações alheias" do Macunaíma, sugere Mário, nasce justamente do fato de que o seu livro "tem um lado objetivo tão fortemente visível”. Dito de outro modo: o desejo de ver as ilustrações de Nava não vem de nenhuma necessidade de suprir qualquer falta de imagens no livro (embora, de fato, a primeira edição não seja ilustrada, a não ser pelo epitáfio figurativo que aparece no segundo capítulo [ANDRADE, 1928, p. 20]), mas, pelo contrário, nasce do fato de que o livro possuiria uma visibilidade intrínseca, sua escrita seria também, em alguma medida, desenho ou pintura: produziria imagens. Não se trata, em suma, de tornar visível o até agora não visível ou pouco visível, mas, sim, de proliferar as formas de visibilidade: multiplicar as imagens, redesenhar os desenhos, recriar as criaturas, redesignar os seres. Proliferação esta que, aliás, não somente tem muito a ver com a história que se conta em Macunaíma, como também converge com uma série de práticas dos modernistas brasileiros que poderíamos talvez compreender como sendo expressões de um desejo de variação. Penso, por exemplo, nas obsessivas retomadas dos mesmos textos por Raul Bopp 5 ou, ainda, na nota que Oswald de Andrade fez anteceder o Serafim Ponte Grande: "Direito de ser traduzido, reproduzido e deformado em todas as línguas" (ANDRADE, 1933, p. 36).

Não é, portanto, um dado externo ao Macunaíma, mas sim, um desdobramento de sua própria vocação múltipla e multiplicadora, que este nos chegue hoje menos como uma obra individual do que como uma coleção de textos e imagens - uma enciclopédia, uma biblioteca, uma coleção, um museu, um Bilderatlas... Não podemos esquecer que o próprio texto do Macunaíma é marcadamente compósito, uma colagem

5 Cf. Sterzi (2012).

Remate de Males, Campinas-SP, v.39, n.1, pp. 246-264, jan./jun. 2019 - 248 
ou montagem de palavras e imagens das mais variadas fontes. Pode-se conceber este livro de Mário de Andrade, portanto, como uma espécie de filtro ou tela que liga uma multiplicidade preexistente - a vasta coleção de imagens e textos mobilizados pelo autor - a uma multiplicidade vindoura - todas as reinterpretações do personagem e de suas peripécias por artistas subsequentes. Se Lévi-Strauss, a propósito do Édipo, pôde dizer - tendo em vista sobretudo a reinterpretação tardia por Freud - que "todas as versões [do mito] pertencem ao mito" (LÉVI-STRAUSS, 1967, p. 252), podemos acrescentar, a propósito do Édipo, pôde dizer - tendo em vista sobretudo a reinterpretação tardia por Freud - que "todas as versões [do mito] pertencem ao mito", podemos acrescentar, a propósito do Macunaíma, que todos os cantos e recantos perfazem a rapsódia (aliás, forma aberta e improvisada por excelência). Impossível, quando relemos hoje o Macunaíma, esquecer a cena do seu nascimento protagonizada por Grande Otelo no filme de Joaquim Pedro de Andrade. É a tal representação cinematográfica, mais do que ao próprio Macunaíma de Mário (mas só porque Grande Otelo é agora também parte do Macunaíma de Mário), que remetem reinterpretações mais recentes como as do diretor teatral José Celso Martinez Corrêa numa sessão de fotografias ou do pintor Daniel Lannes.

Pode-se afirmar que, em Macunaíma, tão importante quanto o trabalho com a linguagem, é o trabalho com a imagem. Haroldo de Campos, a propósito da composição do livro, falou em "imaginação estrutural” (CAMPOS, 1992[1973], pp. 167-182). ${ }^{6}$ A própria lógica das ações, como demonstra Haroldo a partir de uma leitura baseada em Propp (mas também em Jakobson e Barthes, entre outros), forma algo como um diagrama ou ideograma - isto é, uma imagem. ${ }^{7}$ Muito antes de Haroldo de Campos, porém, Nestor Victor (1928, p. 170) - a despeito de todos os seus preconceitos contra alguns aspectos do modernismo brasileiro - já tinha feito uma precisa descrição do Macunaíma em termos de imagens:

Mario empresta a Macunaíma, seu herói, mais à gente de Macunaíma, mãe, amantes, irmãos, etc., o processo onírico, isto é, um modo de pensamento

6 Cf. Campos (1973).

7 Cf. Campos (1977, pp. 23-107).

Remate de Males, Campinas-SP, v.39, n.1, pp. 246-264, jan./jun. 2019 - 249 
regressivo. Ele é próprio à criança como à gente primitiva; aqui, porém, é levado ao seu último grau.

Como nós sonhamos à noite, assim vivem os seus personagens de dia. Tudo em torno desses imaginados seres é sonho e sonho.

Com eles parece que se realiza a existência na quarta dimensão suspeitada pelos einsteineanos. Aquela em que pode ser que vivam os espíritos... Para essa fauna supostamente humana o espaço e o tempo a que vivemos sujeitos não existem. De um instante para outro eles se transportam a distâncias enormes. Além disso, comem ou são comidos, mas daí a pouco voltam ao que eram. Passam por surpreendentes metamorfoses: de um piaba surge um príncipe; um gigante vira besouro.

Vale frisar que essa caracterização - a que já retornarei nos detalhes - é feita no âmbito de algo como uma profecia histórica sobre o papel do índio na formação e no destino do povo brasileiro:

[...] com o índio vivemos na América, e a vida comum estabelece um interesse forçoso. O índio, autóctone ou imigrado, deste continente recebeu o cunho, como nós não o receberemos tão cedo. Mas, um dia virá em que o tenhamos, e aí, mais do que nunca, representando uma humanidade nova, dele seremos irmãos, a ele identificados até nos nossos característicos somáticos. [...] Impõese [...] uma certa solidariedade entre nós e esses primitivos habitantes da terra que lhes tiramos, se não somos estúpidos a ponto de descrer dos nossos próprios destinos remotos (VICTOR, 1928, pp. 168-169).

Como nota Nestor Victor, tanto a Antropofagia quanto especialmente Mário de Andrade retomam a linha suspensa do indianismo romântico, mas de um modo todo outro: "Tratando o assunto inteiramente pelo avesso. Gonçalves Dias, Alencar idealizaram o índio? Pois ele [Mário] antes de tudo pô-lo sem caráter nenhum desde o título" (VICTOR, 1928, p. 170). A chave para essa desidealização é a reproposição da figura do índio através da crítica psicanalítica da civilização, o que, porém, segundo Nestor Victor, poria em risco a concretização daquela profecia histórica de convergência dos povos que o "neoindianismo" modernista anunciava: "O índio, visto com tão furioso freudismo, torna-se um símbolo antecipado da nossa segura bancarrota como povo no correr dos séculos" (p. 173).

Ora, podemos ler as considerações de Nestor Victor a partir do tipo de procedimento que ele detecta no trabalho dos modernistas sobre os indianistas românticos: lendo-as pelo avesso. Nesse sentido, podemos dizer que não está em questão, em Macunaíma, "nossa segura bancarrota como povo no correr dos séculos", isto é, nenhuma bancarrota por vir, mas, sim - se quisermos insistir nos termos do próprio crítico -, a bancarrota como origem. Macunaíma, afinal, não é "símbolo", como disse o próprio 
Mário de Andrade, mas sintoma ${ }^{8}$ (Nestor Victor não erra ao assinalar a perspectiva freudiana do autor) - e, quando se fala em sintoma, é também de um patrimônio quebrado (significado original de bancarrota), isto é, de ruína, que se está falando. O mesmo Mário de Andrade, num poema de celebração do Carnaval carioca dedicado a Manuel Bandeira, usa a fórmula "ruínas de linhas puras" (ANDRADE, 1923, p. 163) ${ }^{9}$ para se referir a algo como a sublimação possível e a inscrição no presente do processo brutal de formação da sociedade brasileira a partir do extermínio dos povos ameríndios e da escravização dos povos africanos - não por acaso, aliás, protagonistas imaginários e efetivos dos festejos carnavalescos. Sublimação e reinscrição, vale frisar, sem anulação das cicatrizes - ou não seriam "ruínas". Relendo pelo avesso o que Nestor Victor escreveu sobre a imaginação no Macunaíma, podemos supor que a adoção do "processo onírico" como princípio compositivo fundamental do livro - sobretudo na forma extremada com que esse processo é aqui mobilizado ("levado a seu último grau”) - é não só uma forma de frisar a preponderância, aqui, da imaginação noturna e selvagem sobre a falta de imaginação diurna e civilizada, mas também do modo de vida indígena sobre o modo de vida do colonizador, que aos poucos se fez colonizado para melhor dar continuidade ao trabalho da colonização (que não cessa, tanto quanto também não cessa a resistência, a "descolonização"). Não por acaso, o predomínio da imaginação, no Macunaíma, é também a primazia da metamorfose contra a fixidez ontológica, é a ruptura das barreiras espaciais e temporais contra o aprisionamento metafísico no presente, é o reino da sobrevivência contra a inevitabilidade da morte. Todos esses gestos intrínsecos ao Macunaíma são igualmente modos de superação do humanismo: "essa fauna supostamente humana", diz Nestor Victor, com compreensão brilhante do que aqui está em jogo (mesmo que à revelia do que ele mesmo porventura pensasse sobre tal tópico).

Antônio Bento, comentando as ilustrações que Carybé fez para o Macunaíma, vê no livro de Mário menos a criação ou reiteração de uma comunidade imaginária que coincidisse com os mitos brasileiros de nação do que uma cesura ou uma quebra em tais discursos:

Quando o Brasil tiver, dentro de poucos anos, uma população de duzentos milhões de habitantes, sua hegemonia, em matéria linguística, irá acentuar-se

8 Cf. Sterzi (2017b, pp. 127-148).

9 Cf. Pucheu e Guerreiro (2011); Passos (1998).

Remate de Males, Campinas-SP, v.39, n.1, pp. 246-264, jan./jun. 2019 - 251 
cada vez mais. E aí ficará constatada concretamente sua projeção no terreno artístico, em relação à antiga comunidade luso-afro-brasileira. O mestre paulista anteviu ainda jovem esta realidade. Foi por isto que ele escreveu o Macunaíma utilizando-se da linguagem corrente do país. E foi igualmente por esse motivo que tomou como modelo do brasileiro comum, a ser retratado, um silvícola do extremo norte da Amazônia e não um mulato ou mestiço do português com negro ou ameríndio (BENTO, 1979, pp. 3-4).

Não se trata, porém, de buscar o mais genuíno, tampouco o mais originário, a não ser, talvez, no sentido benjaminiano de uma origem que é também salto e redemoinho (Ursprung) - e que, instalado em meio ao fluxo da história (o Uraricoera, o Amazonas, o Madeira, o Tietê, segundo a hidrografia de Mário), traz à tona os materiais da gênese e leva para o fundo as formas do presente, produzindo aquelas configurações heterocrônicas e heterológicas de que o modernismo brasileiro, sobretudo em meio ao abalo antropofágico, está repleto. Coincidentemente, Benjamin (1928, p. 32) elabora essa proposta num estudo que, embora escrito três anos antes, só foi publicado no mesmo 1928 do Macunaíma. ${ }^{10}$

Antônio Bento, por sinal, compreendeu como poucos que a história que Macunaíma conta é, sobretudo, a história de um extermínio:

Não desapareceu somente a tribo dos tapanhumas ou tapanhunas (silvícolas escuros), da qual o herói descendeu. O escritor deixa mesmo antever o final dramático da totalidade dos índios brasileiros, no remate de sua história.

Todos vão morrer, sem escapar nenhum deles, com a fatalidade das coisas irremediáveis. [...]

Estão se extinguindo em massa, já agora rápida e irremediavelmente, estes nossos irmãos, vindos dos tupis, guaranis, jês, aruaques ou caribes, não importa o tronco dos seus clãs.

Foi um papagaio que contou as desgraças acontecidas no Uraricoera. A terra tornara-se um "deserto tamanho", no qual foram mortos "os peixes e os passarinhos de pavor e a própria natureza desmaiara e caíra num gesto largado por aí”.

Será que também a Amazônia acabará assim, transformada toda num deserto? O seu desmatamento progressivo é uma trágica realidade (BENTO, 1979, p. 99).

Não parece haver espaço para os indígenas num Brasil que, segundo Antônio Bento, prometia virar no futuro "potência mundial".

Desgraçadamente, serão os antropólogos brasileiros, o ilustre Darcy Ribeiro e outros, que ficarão repetindo tristemente, à maneira do papagaio de bico dourado, os males que estão levando os nossos índios ao extermínio. Todos eles vão desaparecer, com a sua alegria de viver, seus cocares de plumas coloridas,

10 Cf. Agamben (2015, pp. 61-66); Campos (1989, p. 64).

Remate de Males, Campinas-SP, v.39, n.1, pp. 246-264, jan./jun. 2019 - 252 
suas belas máscaras. seus tembetás de lindas pedras verdes, seus objetos bem feitos, suas vistosas pinturas corporais, suas falas, seus cantos, músicas, danças e mitos. Toda a sua cultura vai ser extinta! (BENTO, 1979, pp. 99-10o).

Mário de Andrade é, para Antônio Bento, o "profeta" do "apocalipse dos brasilíndios"(BENTO, 1979, p. 100). Mas, podemos dizer, é ao mesmo tempo o poeta das sobrevivências inquietantes e das persistências perturbadoras. E, antes de tudo: da vida que é incessante metamorfose.

À luz dessa complexidade, ganha mais força a imagem de abertura da série de Carybé: "pode ser encarada como uma síntese de seu contexto. Contém de fato uma visão sumária da rapsódia, quando os índios viviam felizes, no seio do Mato Virgem, tornando-se, ao mesmo tempo, uma narrativa simbólica do sacrifício do herói” (BENTO, 1979, p. 9). Afinal, Macunaíma aparece já morto sobre as pernas de Venceslau Pietro Pietra no centro da ilustração. Frisar o caráter apocalíptico do livro de Mário é, para o crítico, também frisar a sua atualidade e o seu expressionismo. Atualidade que, porém, não cancela os anacronismos, pelo contrário, os convoca:

Tinham de ser expressionistas os desenhos destinados ao livro de Mário de Andrade, que é por sua vez uma obra filiada de preferência a esse movimento, talvez o de maior importância artística neste século, dadas as convulsões sociais que a Humanidade vem atravessando. [...] Às vezes, Carybé parece ter tido a tentação de evocar algo das antigas estampas europeias, que ilustraram os livros de Jean de Lery e Hans Staden, pioneiros na descrição da vida e dos costumes dos brasilíndios. Apesar disso, creio que a similitude resultou mais da temática do que do traço do artista. Este é mais expressionista do que arcaico, na representação dos ambientes indígenas, com aves e bichos do Brasil (BENTO, 1979, p. 8).

Expressionismo é outro modo de nomear, aqui, um estilo apropriado a matéria tão complexa e sobretudo tão perpassada por tensões internas. Diante da ilustração de Carybé para o capítulo "Ursa maior", justamente o capítulo em que Macunaíma é despedaçado, Antônio Bento, indeciso sobre como interpretar uma das figuras desenhadas ("Em cima, Vei, a Sol, dardeja vitoriosamente seus raios e ostenta satisfação em face da tragédia, com sua cabeça humana, sustentada por um corpo de mulher. Seria este corpo o da própria Vei ou de sua filha, rejeitada pelo herói?"), observa que o que importa, para além de qualquer definição, é que se trata de "uma figura antropocosmológica” (BENTO, 1979, p. 94). E, assim, dá ele uma chave para compreendermos a dificuldade que se põe para qualquer um que se proponha ilustrar o livro de Mário de Andrade. Mesmo as figuras mais 
triviais são também, em alguma medida, figuras antropocosmológicas: em todas elas, o humano e o mais-que-humano (mas também o menosque-humano) se dão a ver como combinação complexa. Antropologia e cosmologia, numa obra como Macunaíma (assim como nos mitos que lhe deram origem), são uma só. Isso apenas se torna mais explícito na transformação final do personagem Macunaíma na constelação da Ursa Maior. Essa transformação é, na verdade, menos uma extrapolação do que um reencontro do personagem com sua vocação cósmica.

Uma teoria da imagem a partir de Mário de Andrade tem no ensaio intitulado "Do desenho" um ponto decisivo. Num texto posterior, uma resenha de um livro de contos do pintor Luís Jardim, publicada em 21 de maio de 1939, Mário faz uma síntese daquele ensaio sobre o desenho, deixando claro, de início, o caráter experimental do seu pensamento (e temos de ter em vista sempre esse caráter experimental, quando buscamos depreender uma teoria dos textos de Mário; a teoria, afinal, não deve suprimir essa experimentalidade de origem):

Outro dia, num artigo, como faço frequentemente, joguei algumas ideias meio extravagantes no papel, ideias de que não tenho muita certeza não, só pra ver as reações que despertavam e o destino que teriam na sua luta pela vida. Falava sobre a natureza do desenho e insisti sobre o seu caráter antiplástico. Com efeito, me parece que o desenho, por se utilizar do traço, coisa que já Da Vinci reconhecia não existir no fenômeno visual; por ser uma composição aberta e não fechada, como são pintura, escultura e arquitetura, isto é, não exigir aquelas correlações absolutamente primordiais de volumes, luzes, cores, ritmos, etc.; e finalmente por ter a sua validade imediatamente condicionada ao assunto, exigência que não se dá com as outras artes plásticas: o desenho é na realidade mais uma caligrafia, mais um processo hieroglífico de expressar ideias e imagens, se ligando por isso muito estreitamente às artes da palavra, poesia e prosa (ANDRADE, 1939, p. 48).

No próprio ensaio "Do desenho", Mário dizia que o desenho "é essencialmente uma arte intelectual" (ANDRADE, 1965, p. 65) e que, do discernimento do "caráter antiplástico do desenho" (e portanto de sua contraposição fundamental à pintura e às demais artes visuais), podemos depreender algumas conclusões importantes:

Ele é, ao mesmo tempo, um delimitador e não tem limites, qualidades antiplásticas por excelência. Toda escultura, toda pintura, sendo um fenômeno material, nos apresenta um fato fechado, que se constrói de seus próprios 
elementos interiores, inteiramente desrelacionado com que para uma estátua ou para o quadro seria o não-eu. Os limites da tela, por exemplo, representam para o quadro uma verdade infinitamente poderosa, que se impõe tanto como a disposição dos volumes e das cores, que o pintor escolherá para o seu assunto. [Por sua vez,] o desenho é, por natureza, um fato aberto. Se é certo que objetivamente ele é também um fenômeno material, ele o é apenas como uma palavra escrita. Nós temos dados positivos para saber que, de fato, foi do desenho que nasceu a escrita dos hieroglifos. Não sabemos como se originou a pintura, mas é muito mais provável que a sua primeira conceituação no espírito humano tenha provindo dos rabiscos rituais, em preto, em vermelho, em branco, com que todos os povos primitivos se enfeitam no corpo, para os cerimoniais (ANDRADE, 1965, pp. 65-66).

Fundamental, portanto, no desenho é "desconhece[r] o elemento instintivo da moldura” . O desenho, portanto, aparece aí como uma espécie de figura da liberdade:

Um quadro sem moldura pede moldura; está sempre de alguma forma emoldurado pelos seus próprios e fatais limites de composição fechada. Ao passo que colocar moldura num verdadeiro desenho, que só participe da sua exata natureza de desenho, é uma estupidez que toca as raias do vandalismo. Os amadores do desenho guardam os seus em pastas. Desenhos são para a gente folhear, são para serem lidos que nem poesias, são haicais, são rubais, são quadrinhas e sonetos (ANDRADE, 1965, p. 68).

\section{E há mais:}

O verdadeiro limite do desenho não implica de forma alguma o limite do papel, nem mesmo pressupondo margens. Na verdade o desenho é ilimitado, pois que nem mesmo o traço, esta convenção eminentemente desenhística, que não existe no fenômeno da visão, nem deve existir na pintura verdadeira ou na escultura, e colocamos entre o corpo e o ar, como diz Da Vinci, nem mesmo o traço o delimita. Desenha-se um perfil, por exemplo, e o traço para em meio, ao chegar no colo, ou na raiz da cabeleira. Risca-se a expressão de u'a mão, a que um braço não continua; ou o movimento que fez agora este cabrito. E o cabrito não se apoia num chão (ANDRADE, 1965, p. 68).

Talvez o que importe aí seja precisamente a dialética entre o ilimitado e a mão, entre o cósmico e o antropológico, como razão de base do que é definitivamente inacabado - definitivamente inacabado, aliás, tão característico das poéticas da modernidade. Que a mão, tão humana, seja capaz do ilimitado, que a mão possa fundar, num gesto simples, o sem-limite, parece ser uma das sugestões desse ensaio. Assim como é importante a observação final de que o desenho encerra um tipo de sabedoria congenial à sabedoria "eminentemente transitória" dos provérbios - portanto, também congenial à sabedoria da poesia - e que se 
opõe a toda "verdade eterna, filosoficamente provável” (ANDRADE, 1965, p. 71). Em O banquete, espécie de suma derradeira de sua estética, Mário examinará o desenho a partir do "valor dinâmico do inacabado", o qual, na sua visão, está ligado ao que chama de "arte de combate político" - e que diferencia da arte política convencional, no dizer da época, reproduzido por ele, "arte proletária” ou "arte de tendência social". Para Mário, é, antes, a própria "técnica” que é decisiva na configuração de uma política da arte:

Existem técnicas do acabado, como existem técnicas do inacabado. As técnicas do acabado são eminentemente dogmáticas, afirmativas sem discussão, credo quia absurdum, e é por isto que a escultura, que é por psicologia do material a mais acabada de todas as artes, foi a mais ensinadora das artes ditatoriais e religiosas de antes da Idade Moderna. Bíblias de pedra... Pelo contrário: o desenho, o teatro, que são as artes mais inacabadas por natureza as mais abertas e permitem a mancha, o esboço, a alusão, a discussão, o conselho, o convite, e o teatro ainda essa vitória final das coisas humanas e transitórias com o "último ato" são artes do inacabado, mais próprias para o intencionismo do combate. E assim como existem artes mais propícias para o combate, há técnicas que, pela própria insatisfação do inacabado, maltratam, excitam o espectador e o põem de pé (ANDRADE, 1989[1944-1945], pp. 61-62).

Portanto, para além de uma questão meramente artística, a antiplástica subjacente a essa teoria do desenho - o que nela entra e o que tem de ficar de fora dela - pode ser vista também como parte de uma mais ampla teoria da ação, ou como quer que a chamemos: uma teoria da política, talvez? Pedro A. H. Paixão nos permite ver melhor isso: quando nota, com apoio em Giorgio Agamben, que o desenho, quando passa de circumscriptio a dispositio (e esse trânsito, podemos acrescentar, é constante e nunca se completa: desenho é o que se faz nessa passagem e o que faz essa passagem), traz em si uma ideia de economia e, sobretudo, de separação entre os planos humano e divino (PAIXÃO, 2008, p. 30). Esta ideia é a base da noção de governo, o que faz com que a estrutura do Estado - a burocracia - ganhe a forma de uma espécie de replicação terrena da estrutura celeste: a hierarquia dos anjos, como se sabe, é o modelo da hierarquia dos burocratas (AGAMBEN, 2007, pp. 161-182). ${ }^{11}$ Ora, tais constatações se complicam mais um pouco se lembramos que o próprio Mário de Andrade, por exemplo em carta a Carlos Drummond de Andrade, fez questão de frisar que estava menos interessado nas obras do que nas ações - assinalando, aliás, que Macunaíma nascera precisamente desse privilégio da ação com relação à obra: "Vocês inda estão convencidos

11 Cf. também Agamben e Coccia (2009).

Remate de Males, Campinas-SP, v.39, n.1, pp. 246-264, jan./jun. 2019 - 256 
que estou fazendo obras enquanto não faço senão ações" (SANTIAGO, 2002, p. 264). Ou ainda se lembramos que ele também foi, com constância comparável à de suas atuações como escritor e intelectual, um homem de Estado ou, mais exatamente, um homem de governo. "Me esqueci completamente de mim, sou um departamento de cultura", escreve numa carta famosa (ANDRADE, 2015).

Porém, o mais importante talvez seja perceber como a obra artística de Mário - e, também, sua atuação intelectual mais ampla - não existe em contradição com sua atuação como homem de governo, mas, sim, ganha forma como tensão intrínseca entre as tendências ao governo e ao desgoverno, entre as tendências à hierarquia e aquelas à anarquia. Não estou propondo que se reduza cada uma dessas tensões às outras, mas precisamente que se leia a trajetória global de Mário de Andrade, a partir das imagens e de sua teoria das imagens, sem deixar de abarcar nestas um conjunto de práticas heteróclitas - embora em algum ponto convergentes -, como uma trajetória em que mais do que a adesão a um polo ou outro, a uma prática ou outra, a uma perspectiva ou outra, o que importa parece ser a estruturação sempre polar e tensa do seu pensamento e de sua escrita. Não dá para reduzir obra a Estado e ação a arte, ou vice-versa: o que interessa é perceber que, de um ponto a outro da trajetória de Mário, seu trabalho é atravessado por essas tensões que jamais se resolvem e que se tornam produtivas - ao mesmo tempo que às vezes desesperadoras para o autor - à medida que não se resolvem. E, de fato, a certa altura de O banquete, Mário, pela boca de um de seus personagens, faz o elogio da "arte-ação" - e o hífen é aí decisivo como sinalização de uma dialética cerrada e indecidível (ANDRADE, 1989[1944-1945], p. 132).

Note-se, ademais, que essa dialética entre desenho e pintura, como versão poética de dialéticas políticas mais amplas, volta a se propor em vários outros artistas. Nuno Ramos, por exemplo, contrapõe o princípio subtrativo do desenho ao princípio cumulativo da pintura. Não por acaso, apesar dessa delimitação supostamente clara, os próprios desenhos de Nuno Ramos estão sempre a ser invadidos pela pintura. Porque neles, como no Macunaíma, o que está em questão é a irrupção imprevista dos deuses e dos demônios neste mundo de cá, neste nosso aquém (Penso em séries de desenhos como Anjo e boneco ou Verme anjo, ou ainda Proteu, Confissões de uma máscara, Munch ou Rocha de gritos). 
Pensar a dimensão da imagem em Mário de Andrade, pensar a produtividade que os museus imaginários ou os atlas de imagens ${ }^{12}$ têm em sua obra, é pensar também esses vínculos que a imagem tem com um teoria da ação e da política. Mas é antes de tudo perceber como, por trás de cada imagem singular, há um museu ou um atlas pressupostos o que é um modo de dizer que em toda singularidade pode haver uma multiplicidade implícita (outra intuição política).

Há, quanto a isso, alguns exemplos importantes na trajetória de Mário. O primeiro é a única imagem propriamente dita - isto é, independente de palavras - que aparece no Macunaíma nas edições não ilustradas: é o epitáfio figurativo que Maanape gravou na pedra sob a qual Macunaíma e os irmãos enterraram a mãe. Sobre essa imagem, escreve Telê Porto Ancona Lopez numa nota da edição crítica:

O litógrafo criado dentro do procedimento modernista da colagem, aqui visando ao realismo que valoriza a arte indígena ligada à magia e ao passado arqueológico brasileiro, recaptura, no desenho central, inscrição às margens do rio Japurá, no Pará, exibida por Debret na Voyage pittoresque et historique au Brésil, prancha 30 - "Sculpture en creux" (Paris, Firmin Didot, 1839, Bibl. MA). A ele se associam a inscrição misteriosa, desenho abstrato, e a formiga, esta tirada do traço atual indígena ou de documento rupestre, do tipo dos que foram divulgados por Koch-Grünberg, Von den Steinen, Spix e Martius ou Alencar Araripe (ANCONA LOPEZ, 1996[1928], p. 21, nota).

A imagem aparece aqui como signo de ligação com os mortos: mas ligação através de uma enciclopédia que é também uma coleção.

O segundo exemplo é um curioso autorretrato contido no início de uma carta a Tarsila do Amaral. Esse autorretrato ganha ainda mais significado se sabemos que, na sua coleção de obras de artes plásticas, Mário tinha mais de quarenta retratos seus. Se examinamos essa coleção de retratos, percebemos logo uma nítida contraposição entre uns e outros. Existe uma afirmação apócrifa, atribuída por Flávio de Carvalho a Mário, que daria conta dessa oposição:

Quando olho para o meu retrato pintado pelo Segall, me sinto bem. É o eu convencional, o decente, o que se apresenta em público. Quando defronto o retrato feito pelo Flávio, sinto-me assustado, pois vejo nele o lado tenebroso da minha pessoa, o lado que eu escondo dos outros (MORESCHI, 2015).

12 Para retomarmos uma distinção que Didi-Huberman faz ao contrapor outro homem de estado, que foi também artista, Malraux, a um homem de cultura e que, numa outra época, a nossa, provavelmente seria visto mais facilmente como artista do que como historiador, Aby Warburg. Cf. Didi-Huberman (2013).

Remate de Males, Campinas-SP, v.39, n.1, pp. 246-264, jan./jun. 2019 - 258 
Não se trata de entrar aqui numa discussão sobre a propriedade ou não da afirmação (MORESCHI, 2015). O que importa frisar, agora, é que, se para Mário o desenho é uma forma de ilimitação em sentido positivo, pode ser que a pintura, quando põe de lado a moldura para se concentrar em sua própria materialidade, com a pincelada se fazendo gesto (e voltamos, assim, à questão do expressionismo), parece confrontar o poeta e teórico com uma outra forma do ilimitado, forma temível, sobretudo quando ela se impõe ao retrato do próprio sujeito. Estamos aqui, mais uma vez, diante da dimensão eminentemente sintomática da imagem, justamente aquela explorada em Macunaíma. ${ }^{13}$

Queria, ainda, trazer para a galeria de retratos que acabamos de ver um autorretrato fotográfico muito peculiar: só a sombra sem rosto; sobretudo: o sujeito confundindo-se com o chão, com a terra, mas apenas na medida em que se faz fantasma. Minha sombra é o título. A partir desse autorretrato, sobrepondo nele a figura de Mário e a de Macunaíma, podemos nos perguntar se o nenhum da expressão "herói sem nenhum caráter" não é, mais do que signo de real negatividade ou ausência, uma das formas do múltiplo. É curioso que, na sua coleção, Mário tenha uma aquarela de Flávio de Carvalho muito semelhante à sua fotografia: datada de 1933 e intitulada "Homem", mostra um homem de costas, com as zonas de sombra do corpo demarcadas numa invulgar profusão cromática, que por vezes se aproxima das possibilidades de cor da pele, para logo, porém, se fazer ficção com azuis e amarelos imprevistos.

Encerrando essa série, chegamos a um autorretrato feito apenas de palavras, que por sua vez aludem a imagens. $\mathrm{O}$ museu ou atlas de imagens aparece nos mais inesperados lugares. Neste autorretrato, já encontramos uma antecipação de certa dinâmica corporal macunaímica, que passa pelo sparágmos, pelo despedaçamento dionisíaco do corpo. Escreve Mário nesta carta a Tarsila do Amaral, datada de 7 de janeiro de 1925:

Escrevo esta sob a ação duma ressaca danada. Estou com um gosto de tacho do Alexandrino na boca que não há meios de sair. $\mathrm{O}$ mais pior é que se tenho Alexandrino na boca (salvo seja) o resto é Chagall legítimo. Tudo está virando e separado. Até parece que deixei uma perna lá na cama. Não sinto ela viver comigo. Agorinha mesmo uma roda do bonde lá da Rua das Palmeiras veio correndo, entra que não entra, entrou no meu quarto e botou tudo de cabeça pra baixo. Estou meio ité, meio zonzo e o curumim rindo na esquina parece que guaia dentro do meu ouvido que nem saci em noite de assombração (ANDRADE; AMARAL, 2001, p. 91).

13 Sobre o sintoma, cf. Andrade (1944-1945, p. 66).

Remate de Males, Campinas-SP, v.39, n.1, pp. 246-264, jan./jun. 2019 - 259 
A referência a Pedro Alexandrino se explica pelos tachos de cobre tão presentes em suas naturezas-mortas. Vale lembrar que Alexandrino foi o primeiro professor de Tarsila. Quanto a Chagall, Mário alude à figuração de muitos dos seus personagens que aparecem nas telas como se levitassem. (Vale lembrar que, na ilustração que Carybé fez para a cena da macumba do Macunaíma, ele adota uma técnica muito próxima da de Chagall, com o plano dos deuses ocupado por personagens flutuantes.) Esse autorretrato em pós-êxtase - escrito de "ressaca" - se aproxima muito da figuração da morte definitiva de Macunaíma ao final do livro; mas aqui a fragmentação se dá através de imagens - ou, antes, através de procedimentos imagéticos - tomados de empréstimo ao mundo das artes visuais. Por aqui se compreende, acredito, o papel da coleção e dos museus em Mário: são sempre a possibilidade de uma identidade em aberto, selva de hipóteses de autorretratos que sejam também alterretratos. Juliano Garcia Pessanha cogitou, no lugar de uma autobiografia, uma "heterotanatografia" (PESSANHA, 2002[1999-2000], pp. 37-79). Talvez o que chamemos de literatura, na sua diferença decisiva mas nunca absoluta com relação aos demais discursos, seja sempre uma prática heterotanatográfica, que não apenas substitui, no ato da escrita, o mesmo pelo diverso, a vida pela morte, o real pela ficção, a letra pela imagem, mas sim, a experiência arriscada dos limiares entre uns e outros. A graça de Macunaíma está em arrancar essa experiência dos limites individuais ou privados e transformá-la em locus privilegiado de uma investigação poética e figurativa sobre a "nossa gente" - sem, porém, especificar a delimitação nacional desse nós e dessa gente, uma vez que indígenas e africanos não são exatamente brasileiros (foram integrados à força a uma ficção de nação), mas obrigam a rever a própria ideia de Brasil.

Essa revisão - que faz da obra de Mário, mais do que um esforço de representação do país ou de seu povo, uma sequência de tentativas de figuração, desfiguração e refiguração das imagens do Brasil (eis aí, mais uma vez, o expressionismo do autor) - ganha uma formulação sintética e exemplar na crônica "Flor nacional", publicada no Diário Nacional em 7 de janeiro de 1930. O ponto de partida da crônica é um concurso da revista Rural para eleger "a rainha das flores brasileiras". Mário manifesta-se, no texto, a favor da vitória-régia, que ele descreve, de forma bem-humorada, com atenção à sua fundamental ambivalência, mas, antes de tudo, com atenção também a uma certa resistência à semelhança - e, portanto, a 
uma certa reinvindicação do irrepresentável -, que lhe seria inerente e característica:

Não achei possível se comparar essa flor com outra nenhuma. Perfeição absoluta de forma, e principalmente flor que é declaradamente flor. A gente olha e diz: É flor. Não evoca imagem nenhuma. Não é que nem a rosa que às vezes parece repolho. Ou evoca repolho. Nem feito o cravo que evoca espanador. E muito menos ainda é que nem as parasitas que evocam aeroplano, mapas e o Instituto do Café. Atualmente há um senador por S. Paulo, que apesar de não ser paulista é parecidíssimo com o amor-perfeito. [...]

A vitória-régia é imediatamente flor. E apresenta todos os requisitos da flor. O colorido é maravilhoso, passando, à medida que a flor envelhece, do branco puro, quase verde, ao róseo-moça, ao vermelho-crepúsculo para acabar no roxosujo desilusório. E tem aroma suave. Forma perfeita, cor à escolha, odor. Toda a gente diante dela fica atraído, como Saint-Hilaire ou Martius ante o Brasil. Mas vão pegar a flor pra ver o que sucede! O caule e as sépalas, escondidos na água, espinham dolorosamente. A mão da gente se fere e escorre sangue. O perfume suavíssimo que encantava de longe, de perto dá náusea, é enjoativo como o quê. E a flor, envelhecendo depressa, na tarde abre as pétalas centrais e deixa ver no fundo um bandinho nojento de besouros, cor de rio do Brasil, pardavascos, besuntados de pólen. Mistura de mistérios, dualidade interrogativa de coisas sublimes e coisas medonhas, grandeza aparente, dificuldade enorme, o melhor e o pior ao mesmo tempo, calma, tristonha, ofensiva, é impossível a gente ignorar que nação representa essa flor... (ANDRADE, 1976[1930], pp. 183-184).

Contra os previsíveis mitos de identidade, Mário propõe uma fábula da pluralidade - fábula, aliás, plural na sua própria constituição, já que construída por meio de procedimentos como a montagem e a colagem (de textos e imagens, mitos e conceitos alheios), de modo a que o próprio um se revele intrinsecamente vário; em suma, uma confabulação. É por meio dessa fábula que assistimos à irrupção de todas as línguas na língua, de todas as imagens na imagem, de todos os povos no povo.

\section{REFERÊNCIAS}

AGAMBEN, Giorgio. Angelologia e burocrazia. In: Il regno e la gloria. Per una genealogia teologica dell'economia e del governo (Homo sacer, II, 2). Vicenza: Neri Pozza, 2007, pp. 161-182.

AGAMBEN, Giorgio. Vortici. In: Il fuoco e il racconto. Roma: Nottetempo, 2015, pp. 61-66.

AGAMBEN, Giorgio; COCCIA, Emanuele (orgs.). Angeli. Ebraismo Cristianesimo Islam. Vicenza: Neri Pozza, 2009.

ANCONA LOPEZ, Telê Porto. [Notas à edição crítica.] In: ANDRADE, Mário de. Macunaíma, o herói sem nenhum caráter. Ed. crítica Telê Porto Ancona Lopez. 2. 
ed. Madri/Paris/México/Buenos Aires/São Paulo/Rio de Janeiro/Lima: ALLCA XX, $1996[1928]$.

ANDRADE, Mário de. Flor nacional. In: Táxi e crônicas no Diário Nacional. Ed. Telê Porto Ancona Lopez. São Paulo: Duas Cidades/Secretaria da Cultura, Ciência e Tecnologia, 1976[1930], pp. 183-184.

ANDRADE, Mário de. Do desenho. In: Aspectos das artes plásticas no Brasil. Belo Horizonte: Itatiaia, 1984[1965], pp. 65-71.

ANDRADE, Mário de. Carnaval carioca [1923]. In: Clã do Jabuti [1927]. Hoje em Poesias completas. Ed. crítica Diléa Zanotto Manfio. Belo Horizonte/São Paulo: Itatiaia/ Edusp, 1987, p. 63.

ANDRADE, Mário de. O banquete. São Paulo: Duas Cidades, 1989[1944-1945].

ANDRADE, Mário de. Macunaíma, o herói sem nenhum caráter. Ed. crítica Telê Porto Ancona Lopez. 2. ed. Madri/Paris/México/Buenos Aires/São Paulo/Rio de Janeiro/ Lima: ALLCA XX, 1996[1928].

ANDRADE, Mário de. Pintor contista (1939). In: O empalhador de passarinho. Rio de Janeiro: Nova Fronteira, 2012[1944].

ANDRADE, Mário de. Me esqueci completamente de mim, sou um departamento de cultura. Org. Carlos Augusto Calil e Flávio Rodrigo Penteado. São Paulo: Imprensa Oficial, 2015.

ANDRADE, Mário de; AMARAL, Tarsila do. Correspondência Mário de Andrade E Tarsila do Amaral. Org. Aracy Amaral. São Paulo: Edusp/Instituto de Estudos Brasileiros, 2001.

ANDRADE, Oswald de. Serafim Ponte Grande. São Paulo: Globo, 1992[1933].

BENJAMIN, Walter. Origem do drama trágico alemão. Trad. João Barrento. Lisboa: Assírio \& Alvim, 2004[1928].

BENTO, Antônio. Comentários de Antônio Bento. In: CARYBÉ; BENTO, Antônio. Macunaíma. Ilustrações do mundo do herói sem nenhum caráter. Edição comemorativa do cinquentenário da publicação de Macunaíma, o herói sem nenhum caráter, de Mário de Andrade. 1928-1978. Rio de Janeiro/São Paulo: Livros Técnicos e Científicos/Editora da Universidade de São Paulo, 1979.

CAMPOS, Haroldo de. Morfologia do Macunaíma. São Paulo: Perspectiva, 1973.

CAMPOS, Haroldo de. O sequestro do Barroco na Formação da literatura brasileira: o caso Gregório de Mattos. Salvador: Fundação Casa de Jorge Amado, 1989. 
CAMPOS, Haroldo de. Mário de Andrade: a imaginação estrutural. In: Metalinguagem E outras metas. Ensaios de teoria e crítica literária. 4. ed. rev. e ampl. São Paulo: Perspectiva, 1992[1973], pp. 167-182.

CAMPOS, Haroldo de. Ideograma, anagrama, diagrama. Uma leitura de Fenollosa. In: CAMPOS, Haroldo de (org.). Ideograma. Lógica, poesia, linguagem. Trad. Heloysa de Lima Dantas. 3. ed. São Paulo: Edusp, 1994[1977], pp. 23-107.

DIDI-HUBERMAN, Georges. L'album de l'art à l'époque du Musée imaginaire. Paris: Hazan/Musée du Louvre, 2013.

LÉVI-STRAUSS, Claude. A estrutura dos mitos. In: Antropologia estrutural. Trad. Chaim Samuel Katz e Eginardo Pires. Rio de Janeiro: Tempo Universitário, 1967, pp. 237-265.

MORESCHI, Marcelo. Mário de Andrade como ruína psicoetnográfica: o retrato de Flávio de Carvalho. Peixe-elétrico, n. 1, jul. 2015, pp. 6-36.

PAIXÃO, Pedro A. H. Desenho. A transparência dos signos. Estudos de teoria do desenho e de práticas disciplinares sem nome. Lisboa: Assírio \& Alvim, 2008.

PASSOS, José Luiz. Ruínas de linhas puras. Quatro ensaios em torno a Macunaíma. São Paulo: Annablume, 1998.

PESSANHA, Juliano Garcia. Heterotanatografia. In: Certeza do agora. Cotia: Ateliê, 2002[1999-2000], pp. 37-79.

PUCHEU, Alberto; GUERREIRO, Eduardo (orgs.). O carnaval carioca de Mário de Andrade. Rio de Janeiro: Azougue, 2011.

ROSSETTI BATISTA, Marta; SOARES DE LIMA, Yone. Coleção Mário de Andrade. Artes plásticas. 2. ed. rev. e ampl. São Paulo: Instituto de Estudos Brasileiros/Universidade de São Paulo, 1998.

SANTIAGO, Silviano (org.). Carlos E Mário. Correspondência de Carlos Drummond de Andrade e Mário de Andrade. Rio de Janeiro: Bem-Te-Vi, 2002.

STERZI, Eduardo. A irrupção das formas selvagens. In: ANDRADE, Mário. Macunaíma, o herói sem nenhum caráter. São Paulo: Ubu, 2017a, pp. 219-222.

STERZI, Eduardo. Brasil-sintoma: como viver na pós-história?. In: PATIÑO, Roxana; CÁMARA, Mario (orgs.). Por qué Brasil, qué Brasil? Recorridos críticos. La literatura y el arte brasileños desde Argentina. Villa María: Eduvim, 2017b, pp. 127-148.

STERZI, Eduardo. Resenha de Movimentos modernistas do Brasil: 1922-1928, de Raul Bopp. O Globo, blog Prosa, 4 fev. 2012. Disponível em: <https://blogs.oglobo.globo.com/ prosa/post/resenha-de-movimentos-modernistas-do-brasil-1922-1928-de-raulbopp-431434.html>. 
STERZI, Eduardo; STIGGER, Veronica. Variações do corpo selvagem: Eduardo Viveiros de Castro, fotógrafo. São Paulo: Sesc São Paulo, 2017.

VICTOR, Nestor. Macunaíma. In: Os de hoje. Figuras do movimento modernista brasileiro. São Paulo: Cultura Moderna, 1938.

Recebido: 31/01/2019

Aceito: 26/04/2019

Publicado: 11/07/2019

Remate de Males, Campinas-SP, v.39, n.1, pp. 246-264, jan./jun. 2019 - 264 